\title{
RESPIRATORY AND METABOLIC MANAGEMENT IN ACUTE TETRAPLEGIA
}

\author{
By D. J. E. Cheshire, M.B., B.S., D.Phys.Med., \\ Spinal Injuries Centre, Austin Hospital, Heidelberg, Victoria, Australia \\ and \\ D. A. Coats, M.B., B.S., \\ The Department of Physiology, University of Melbourne
}

THE management of a patient with acute tetraplegia is beset with many different problems. The problems may be divided into those associated with the injury to the spine and spinal cord, those associated with other common complications such as head, chest and limb injuries, and those associated with the respiratory and metabolic consequences of this type of injury. The term injury includes not only the accidental trauma but also, where necessary, subsequent operative treatment, with or without general anaesthesia. On occasions there may be days or even weeks between these components of the 'injury'. In a previous paper (Cheshire, I964) a broad plan for respiratory assessment and management was suggested, and while the hypoventilation syndrome, the management of a tracheostomy and the effects of body temperature on the oxygen requirements of the tetraplegic patient will be discussed in this paper, its primary purpose is to present the special metabolic problems of the acute tetraplegic and to propose a regime for the co-ordinated treatment of respiratory and metabolic states.

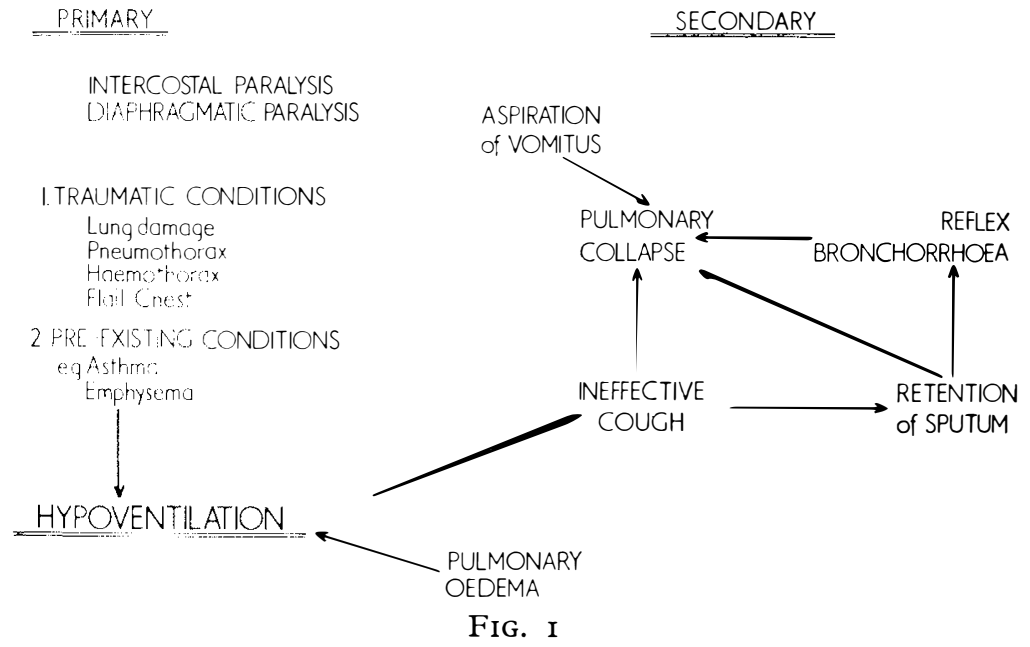

The causes and effects of Hypoventilation-modified from Grant et al. (1962).

Hypoventilation. In the tetraplegic patient alveolar ventilation may be impaired either directly as a result of spinal cord trauma and associated injuries or pre-existing lung disease, or secondarily because of the consequences or complications of hypoventilation (fig. I). The presence or absence of the primary causes is determined during the initial clinical examination of the patient, and an attempt must then be made to determine whether or not ventilation is, and is likely to 
remain, adequate. It is not possible to make such an assessment on clinical grounds alone, and reference must be made to respiratory function tests and biochemical tests. It is at this point that care must be exercised, because the standards of normality are not those of the able-bodied but those of a comparable, stabilised tetraplegic. The comparison involves similarity in sex, age, body surface area and level of cord injury.

The use of a ventilation meter, such as the Wright 'Respirometer', will readily permit an estimate of tidal volume and vital capacity to be made. Experience shows (Cheshire, 1964) that, in the absence of complications, such as the secondary causes of hypoventilation or any cause of hyperthermia, whilst they are of ten higher, a tidal volume of $200 \mathrm{ml}$. or a vital capacity of $800 \mathrm{ml}$. may be adequate to maintain the tetraplegic under basal conditions. These figures are below those given by an average sample of stabilised tetraplegics (Table I), who because of their activity are no longer under basal conditions.

TABLE I-Tidal Volumes and Vital Capacities in Stabilised Tetraplegics

\begin{tabular}{|c|c|c|c|c|c|}
\hline Subject & $\begin{array}{l}\text { Age } \\
\text { (Yrs) }\end{array}$ & $\begin{array}{c}\text { Cervical Cord } \\
\text { Lesion }\end{array}$ & $\begin{array}{c}\text { Time } \\
\text { Since } \\
\text { Accident } \\
\text { (Months) }\end{array}$ & $\begin{array}{c}\text { Tidal } \\
\text { Volume } \\
\text { (ml) }\end{array}$ & $\begin{array}{l}\text { Vital } \\
\text { Capacity } \\
(\mathrm{ml})\end{array}$ \\
\hline 1. (G.B.) & 21 & Complete below $\mathrm{C} 6$ & 3 & 310 & 2200 \\
\hline 2. (B.R.) & 27 & Complete below C6 & 3 & 460 & 2000 \\
\hline 3. (D.C.) & 14 & Complete below C6 & 4 & 445 & 2000 \\
\hline 4. (A.M.) & 19 & Complete below C5 & 23 & 500 & 1950 \\
\hline 5. (B.P.) & 28 & Complete below C5 & 33 & 530 & 3000 \\
\hline 6. (B.S.) & 29 & Complete below C5 & 38 & 250 & 1500 \\
\hline 7. (A.P) & 46 & Complete below C6 & 39 & 470 & 1550 \\
\hline 8. (K.R.) & 23 & Complete below C6 & 42 & 265 & 2200 \\
\hline 9. (S.E.) & 38 & Complete below C6 & 64 & 500 & 1100 \\
\hline 10. (G.S.) & 28 & Complete below C6 & 110 & 220 & 1200 \\
\hline
\end{tabular}

Be:gofsky (Ig64) hias recentily dernonstiated that, in abi-jodied subjects in the supine position, a mean value of 37 per cent. of the tidal volume results from diaphragmatic action, and 63 per cent. from action of the rib cage. In the tetraplegic the diaphragm is the only major functioning muscle of respiration, and the work done by the diaphragm in pushing aside abdominal viscera was calculated as 
being nine times greater than in the able-bodied. Bergofsky postulates that this increased expenditure of effort gives rise to dyspnoea which is minimised by a decrease in respiration rate. Normal alveolar ventilation may be achieved by greater economy in breathing with a decreased respiratory rate and an increased tidal volume.

Bergofsky claims that an inadequate respiratory rate is the basis of chronic alveolar hypoventilation which he observed in four tetraplegic patients with $\mathrm{pCO}_{2}$ values of 44 to $52 \mathrm{~mm}$. $\mathrm{Hg}$.

TABLE II-Blood Gases in Stabilised Tetraplegics

\begin{tabular}{|c|c|c|c|c|c|c|}
\hline Subject & $\begin{array}{l}\text { Age } \\
\text { (Yrs) }\end{array}$ & $\begin{array}{l}\text { Cervical Cord } \\
\text { Lesion }\end{array}$ & $\begin{array}{c}\text { Time } \\
\text { Since } \\
\text { Accident } \\
\text { (Months) }\end{array}$ & $\mathrm{pH}$ & $\begin{array}{l}\text { Carbon } \\
\text { Dioxide } \\
\text { Tension } \\
\left(\mathrm{pCO}_{2}\right) \\
(\min \mathrm{Hg})\end{array}$ & $\begin{array}{c}\text { Plasma } \\
\text { Actual } \\
\text { Bicarbonate } \\
\text { Concentration } \\
(\mathrm{mEq} / 1)\end{array}$ \\
\hline 1. (G.B.) & 21 & Complete below C6 & 3 & 7.41 & 47 & 30 \\
\hline 2. (B.R.) & 27 & Complete below C6 & 3 & 7.49 & 39 & 29 \\
\hline 3. (D.C.) & 14 & Complete below $\mathrm{C} 6$ & 4 & 7.44 & 38 & 25 \\
\hline 4. (A.M.) & 19 & Complete below C5 & 23 & 7.40 & 49 & 28 \\
\hline 5. (B.P.) & 28 & Complete below C5 & 33 & 7.43 & 28 & 17 \\
\hline 6. (B.S.) & 29 & Complete below C5 & 38 & 7.38 & 41 & 23 \\
\hline 7. (A.P.) & 46 & Complete below C6 & 39 & 7.41 & 38 & 23 \\
\hline 8. (K.R.) & 23 & Complete below C6 & 42 & 7.39 & 43 & 25 \\
\hline 9. (S.E.) & 38 & Complete below C6 & 64 & 7.40 & 47 & 29 \\
\hline 10. (G.S.) & 28 & Complete below C6 & 110 & 7.38 & 47 & 28 \\
\hline
\end{tabular}

In the light of opinion previously expressed in the literature (Hemingway et al., 1957), that arterial blood gases in tetraplegics are normal, it was felt to be essential to re-examine this question, and Io complete tetraplegic males were selected for investigation. The subjects were selected on the criteria of (I) their being in hospital at the time in question, (2) their ability to attend the laboratory in a wheelchair, (3) the absence of any pre-accident history of respiratory disease and (4) the absence of any respiratory disease after the acute phase of their traumatic tetraplegia. Samples of capillary blood were taken, and the carbon dioxide tension determined with a $\mathrm{pH}$ meter, using the micro-Astrup method (Siggaard Andersen et al., I960) and the Siggaard Andersen nomogram (I96I).

The results of this investigation (Table II), in patients with functionally 
adequate gaseous exchange, show $\mathrm{pCO}_{2}$ values in the range 28 to $49 \mathrm{~mm}$. $\mathrm{Hg}$. These patients showed no evidence of hypercapnia or lowered $\mathrm{pH}$, and for this reason it becomes obvious that an isolated seemingly high $\mathrm{pCO}_{2}$ value cannot of itself constitute an indication for tracheostomy.

Blood gas analyses in the tetraplegic patient should be interpreted in the light of their reduced activity. It is not uncommon in thoracic surgical literature to read that criteria for tracheostomy and assisted respiration include an arterial oxygen saturation of less than 94 per cent. and an arterial carbon dioxide tension greater than $50 \mathrm{~mm}$. of mercury (Grant et al., I962). The slope of the oxygen dissociation curve is such that a reduction of arterial oxygen saturation below 90 per cent. does not occur till the alveolar oxygen tension has fallen to $60 \mathrm{~mm}$. Hg.; that is, until ventilation is reduced almost by half. But an oxygen tension of $60 \mathrm{~mm}$. $\mathrm{Hg}$. is compatible with the maximum physical capacity of a stabilised tetraplegic, and it is felt that measurement of the oxygen tension, because of the shape of the curve in this region, is of little value in the assessment and treatment of the acute tetraplegic.

The carbon dioxide tension is a much more sensitive index of ventilatory function and, provided that an initial estimation is considered in relation to tetraplegic and not to able-bodied values, subsequent estimations are of the greatest value in following the patient's progress. In the assessment of the adequacy of gaseous exchange, estimates of carbon dioxide tension are to be preferred. Plasma bicarbonate concentrations reflect not only respiratory adequacy with respect to gaseous exchange, but also the respiratory component of compensation for a large number of metabolic stresses which may be applied to the acid-base economy in the tetraplegic patient.

Respiratory Management. The respiratory management of the acute tetraplegic consists essentially of the maintenance of an adequate state of alveolar ventilation. If ventilation be adequate at the time of initial assessment it then becomes necessary to preserve that state by the prevention of the avoidable complications of respiratory paralysis. These complications include;

I. Pulmonary Collapse. Aspiration of vomitus is particularly liable to cause pulmonary collapse, and vomiting is prevented by the passage of a naso-gastric tube and repeated aspiration of the gastric contents.

2. Pulmonary Infection. Infection is minimised by the use of prophylactic antibiotics.

3. Pulmonary Oedema. Pulmonary oedema due to over-hydration is avoided by strict supervision of the fluid intake.

4. Ineffective Cough. The tetraplegic has an ineffective cough due to paralysis of the intercostal and abdominal muscles. This ineffective cough may be the cause of sputum retention and pulmonary collapse, and be the major factor in the vicious circle of secondary hypoventilation (fig. I). Treatment includes vigorous chest physiotherapy, assisted coughing and postural drainage in the head down position (Cameron et al., I955).

At this stage of the patient's management the question of tracheostomy may arise. The indications for, and management of, a tracheostomy have been discussed in a previous paper (Cheshire, I964), but further experience has resulted 
in a revision and extension of opinion concerning the topics of humidification, drugs and endo-bronchial suction.

Humidification. Once a tracheostomy is established for any reason it becomes essential to maintain a normal physiological environment within the tracheo-bronchial tract, as establishing a tracheostomy removes the protective functions which normally guard the lower respiratory passages. Most of the complications in the management of a tracheostomy (Meade, I96I; Watts, I963) can be related to inadequate humidification of the inspired atmosphere, and Grant et al. (1962) have described a vicious circle of tracheo-bronchitis (fig. 2) which results from dehydration of the air passages and subsequent efforts to suck out viscous sputum.

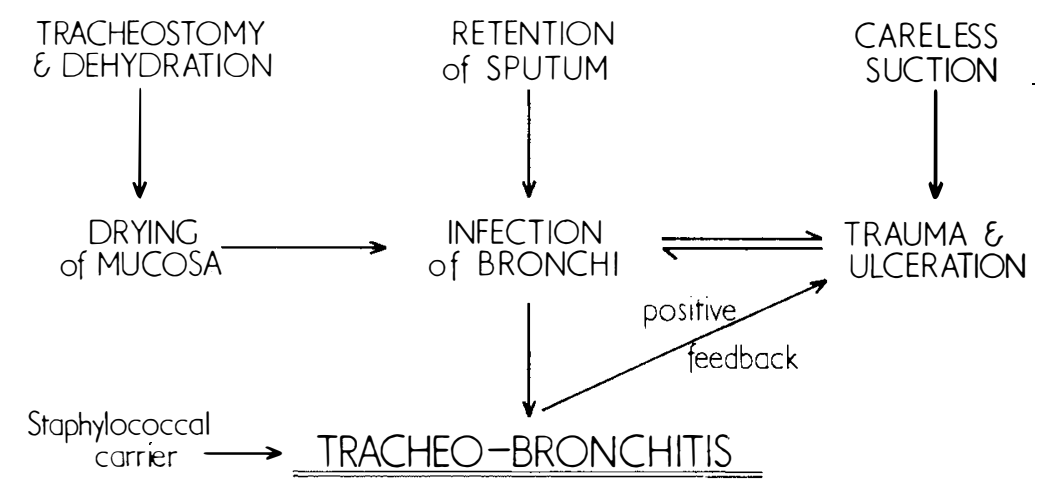

FIG. 2

The vicious circle of tracheo-bronchitis-modified from Grant et al. (1962).

The maintenance of a normal physiological environment has special reference to ciliary function, as the-cilia can function efficiently only if they are bathed continuously in mucus, which is adequate in amount and of the correct consistency. The factors involved, temperature, oncotic and ionic factors, hydrogen ion concentration and hydration have been reviewed by Sara (1965) who concludes that adequate humidification is maximally efficacious in liquefying mucus, and that drugs, including proteolytic enzymes, detergents, and sodium bicarbonate are either inefficient, or, more important, dangerous in that they may depress or destroy cilia by alteration of the hydrogen ion concentration beyond the range at which ciliary action ceases $(\mathrm{pH} 8 \cdot 0)$.

In two papers Sara (1965) describes experiments in humidification of the inspired atmosphere and reaches the conclusion that adequate humidification at the optimum temperature is best obtained by nebulisation of warmed water, and the Puritan nebuliser ${ }^{1}$ is said to give satisfactory results. This nebuliser, which incorporates a heating coil and a thermostat, is conveniently used in conjunction 
with the Bird Intermittent Positive Pressure Respirator ${ }^{1}$ (fig. 3), the use of which has been previously commended in the management of the acute tetraplegic (Cheshire, 1964).

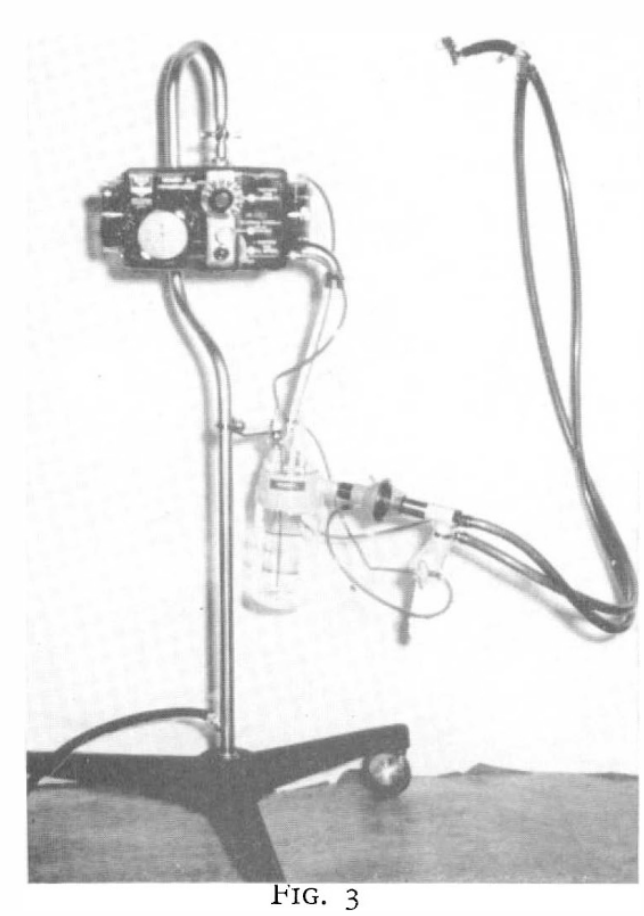

The Bird Intermittent Positive Pressure Respirator, with Puritan Nebuliser attached.

The combined use of the Bird Respirator and Puritan nebuliser to provide a warmed, humidified airoxygen mixture is thought to constitute a further advance in the management of these patients.

Drugs. As previously mentioned, evidence is acccumulating of the limited value of proteolytic enzymes (Taylor, I960; Bremner, I962) and also that the use of sodium bicarbonate may depress ciliary function. Hence, with the opportunity to provide the patient with a warmed humidified atmosphere, these drugs have been discontinued, and the use of drugs is now restricted to antibiotics and, when indicated, a broncho-dilator, which is administered six-hourly in aerosol form, using the Bird mainstream nebuliser. A suitable broncho-dilator is I-(3, 5 diphenylhydroxyphenyl)-2isopropylamino-ethanol sulphate'Alupent', which is prescribed in a dose of I ml. of a 2 per cent. solution (20 mg.).

Endo-tracheal and Endo-bronchial Suction. In the management of a tracheostomy, sputum retention is a potent factor in the vicious circle of hypoventilation, and also, in combination with careless suction, in the vicious circle of tracheo-bronchitis. For these reasons it is felt that adequate hydration and adequate, minimally traumatic suction are the fundamentals of successful management. In a previous paper (Cheshire \& Foster, 1964) an alternative technique for endobronchial suction was described, and further use has confirmed the efficacy of this method which permits endo-bronchial suction to be performed with frequency and safety. In appropriate circumstances the virtues of frequent endo-bronchial suction are self-evident, but evidence of the safety of the procedure for longterm use required further demonstration, which was forthcoming in the following case history;

A 19-year-old male sustained a complete forward dislocation of C6 on 7 (fig. 4) in a motor accident. On examination, I7 hours after the accident, he presented a complete flaccid paralysis below $\mathrm{C}_{4}$ on the left and $\mathrm{C}_{5}$ on the right, with total sensory loss below

${ }^{1}$ Bird I.P.P.R.: Bird Oxygen Breathing Equipment, California. 
C5 bilaterally. He had not vomited, his chest was clinically clear, and his respiratory status was adequate.

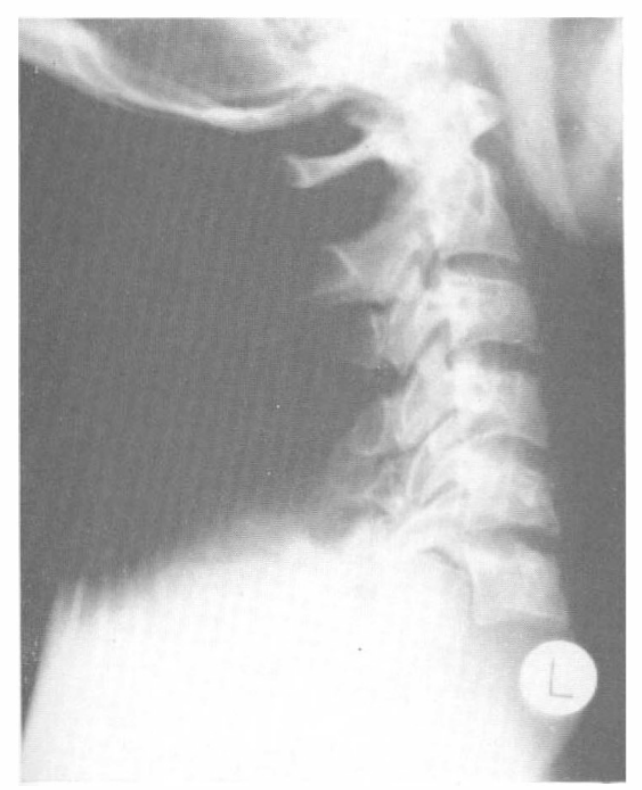

FIG. 4

Complete forward dislocation of $\mathrm{C} 6$ on $\mathrm{C}_{7}$.
On the second day there was clinical and radiological evidence of collapse and consolidation of the upper lobe of the right lung (fig. $5(a)$ ), and difficulty in clearing secretions from the chest. For these reasons, and despite normal biochemical findings, a tracheostomy was performed. On the third day, the motor and sensory levels had risen to $\mathrm{C}_{4}$, the carbon dioxide tension was $43.5 \mathrm{~mm}$. $\mathrm{Hg}$., the plasma bicarbonate was $35.6 \mathrm{mEq} . / 1$., and a moderate amount of muco-purulent sputum was being aspirated from both sides of the chest. Assisted respiration was commenced.

By the fifth day, there was radiological evidence of re-expansion of the right upper lobe, but some patchy consolidation was evident in the left mid-zone (fig. $5(b)$ ). Bio-chemical findings were normal. On the sixth day, the left lung was radiologically clear, and on the seventh day there was almost complete resolution of the con-

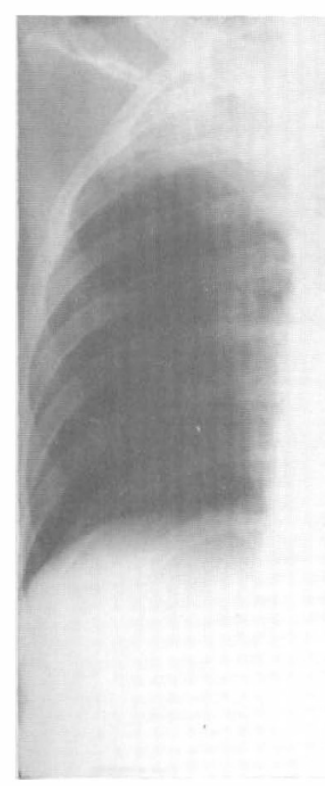

$a$

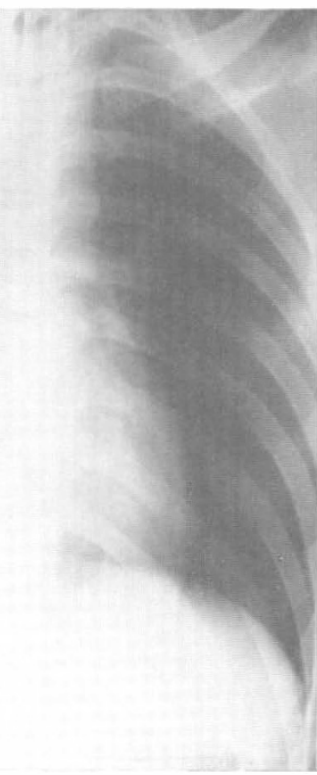

FIG. 5

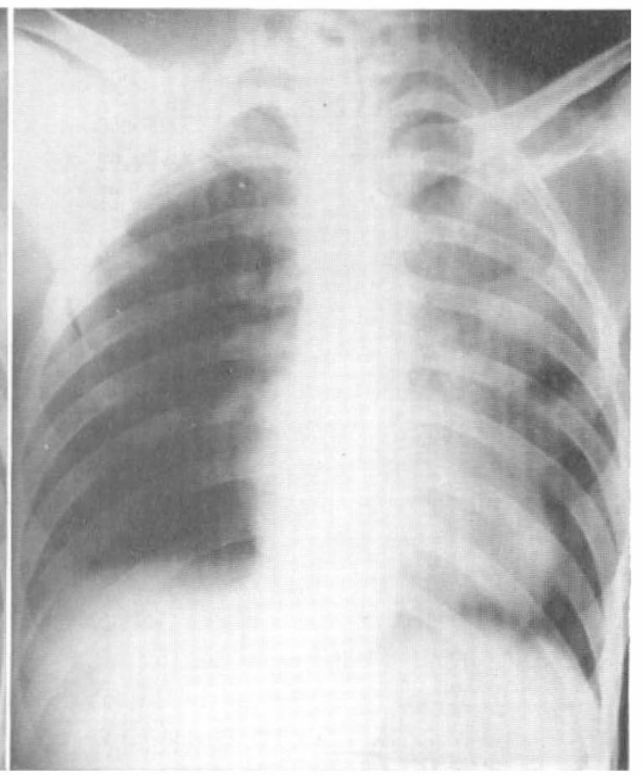

$b$

(a) Collapse and consolidation of the upper lobe of the right lung.

b) Some expansion of right upper lobe, but patchy consolidation in left mid-zone. 
solidation and re-expansion of the right upper lobe. During these days endo-bronchial suction had been performed twice daily in addition to the standard routine of postural drainage, physiotherapy and endo-tracheal suction.

The lesion remained complete below $\mathrm{C}_{4}$, and assisted respiration was continued. On the Ioth day collapse of the right upper lobe was again evident, and partial collapse and consolidation was present in the right upper lobes till the 2oth day, as well as left upper lobe consolidation during the middle of this period. On the I 5 th day bronchoscopy was performed through the tracheostomy stoma, and mucopurulent secretions were seen in the trachea, having come from the right upper lobe bronchus which was slightly inflamed. The remainder of the bronchial tree was normal, with healthy mucosa and no secretions.

From the 20th day the chest remained radiologically normal, but endo-bronchial suction was used whenever there was clinical evidence of retained secretions. On the 23 rd day flickers of voluntary function reappeared in the deltoid on both sides, the sensory level had descended into the $\mathrm{C}_{5}$ dermatome, and a gradual improvement was maintained until, on the 45th day, the tracheostomy was closed. The neurological function on that day was power 3 (M.R.C. Scale) in the deltoid and biceps on the right side, and power 2 on the left, and normal sensation in $\mathrm{C}_{5}$. Respiratory function was tidal volume $550 \mathrm{ml}$., and vital capacity $1350 \mathrm{ml}$. Immediately prior to closing the tracheostomy, bronchoscopy was performed, and showed an essentially normal bronchial tree except that there was minimal inflammation in the segmental divisions of the right lower lobe.

Twelve weeks after the accident there is motor and sensory function in the C6 segment, a tidal volume of $500 \mathrm{ml}$., and a vital capacity of $2000 \mathrm{ml}$.

Not least important in the foregoing illustration is the continuing liability of the upper lobe of the lung to episodes of collapse, particularly on the right side. The difficulty in aspirating the right upper lobe bronchus makes it the more important to prevent dehydration and its consequences.

Temperature Control. The inability of the tetraplegic to control his body temperature is well known, and at no time is this so apparent as in the immediate post-accident period. In hot climates environmental hyperthermia can cause serious embarrassment and has led to the nursing of these patients in air-conditioned wards. Experience has shown that the complete tetraplegic nursed without blankets in a constant temperature of $21^{\circ} \mathrm{C}$. $\left(70^{\circ} \mathrm{F}\right.$.) will stabilise at a body temperature of 34 to $35^{\circ} \mathrm{C}$. (rectal), and this finding has led to speculation on the possible benefits to be gained from even a slight reduction in body temperature.

Previous reference has been made to the desirability of maintaining the patient under basal conditions, and in the acute tetraplegic these conditions include enforced recumbency, and the physiological factors of peripheral vaso-dilatation, almost total flaccid paralysis and the inability to shiver. The value of the clinical use of hypothermia lies in a reduction in the oxygen requirements of living tissues as their temperature falls (Benedict \& Lee, 1938; Smith \& Fay, 1940), and from available evidence (Bigelow et al., I950; Horvath et al., I953), oxygen requirements at $34^{\circ} \mathrm{C}$. are approximately 20 per cent. less than at $37^{\circ} \mathrm{C}$.

The clinical use of hypothermia, as in cardio-vascular surgery, brings in its train biochemical problems such as both respiratory and metabolic acidosis, but these are not significant with a fall of only three degrees. Nonetheless, the special characteristics of the physiology of the acute tetraplegic are such as to suggest there may be therapeutic advantages in permitting this spontaneous cooling to occur. Conversely, the disadvantages of hyperthermia, due to either environment or infection, are obvious. 


\section{METABOLIC AND ACID-BASE DISTURBANCES.}

Patients admitted to a Spinal Unit with acute traumatic tetraplegia may have come directly from their accident or may previously have been admitted to and treated in another hospital. In the latter event the difficulties of management may be significantly increased because of one or more of a number of complicating factors. The most common of these, and the ones causing the greatest difficulty in the subsequent management of the patients are:

(a) Fluid Overloading. This occurs particularly with intravenous isotonic sodium chloride solutions with or without low concentrations of glucose. This type of therapy is undesirable for many reasons, among which are the possibility of causing pulmonary oedema, peripheral oedema, sodium overloading (particularly as after the injury the patient is likely to have a positive sodium balance due to enhanced mineralo-corticoid activity) and chloride overloading with a consequent stress on the body's buffer systems.

(b) Potassium Depletion. Failure to provide an adequate potassium intake will delay the restoration of normal smooth muscle function (Marks, I950). Potassium requirements after spinal injury may be high, and in our patients intravenous potassium up to $300 \mathrm{mEq}$. in 24 hours has been necessary to achieve a positive potassium balance and to restore deficits. Failure to restore the potassium deficiency following injury leads to impairment of cardiac and smooth muscle function associated with intracellular sodium loading and extracellular hyponatremia. That potassium deficits may be very large and that their restoration may require intensive therapy has been known for a number of years. Elkington and Tarail (1950) have drawn attention to potassium deficits of 900 to $1000 \mathrm{mEq}$. and the same authors (Tarail \& Elkington, I949) have indicated the therapy necessary to correct these deficits. Yet in our experience it has been unusual to receive from other hospitals tetraplegic patients who have received more than $25 \mathrm{mEq}$. potassium per day, and usually they have received none.

(c) Starvation. The most common nutrient solution provided to patients subsequently transf erred to our Unit has been 4 per cent. dextrose in 0.18 per cent. saline. This solution provides approximately $\mathrm{I} 60 \mathrm{kcal}$. per litre and, even though the patients referred to us have of ten been subjected to gross fluid overloading with its attendant dangers, their caloric intake has rarely exceeded $500 \mathrm{kcal}$. per day and has usually been less. The average adult patient with a body surface area of I. 5 to I $\cdot 8 \mathrm{sq}$. metres has a basal caloric requirement of approximately I 500 to I $800 \mathrm{kcal}$. per day and his requirements following injury and with possible associated infection are considerably higher. The body's readily available carbohydrate, however, is strictly limited and Levine (I959) has indicated a total body carbohydrate reserve in an average healthy adult man of about 370 grams, equal to less than I500 kcal. With grossly inadequate caloric intakes the body's glycogen stores are thus rapidly depleted, often in less than 24 hours, and a negative nitrogen balance and starvation ketosis are early and inevitable consequences. The combination of starvation ketosis with a metabolic acidosis as part of the reaction to injury constitutes a major stress to the body's buffer systems. The added dangers of saline overloading, which were noted by Coller and Maddock as early as I940 and have been reviewed 
by Geyer (1960), should draw attention to the fact that 4 per cent. dextrose in 0.18 per cent. saline and 0.9 per cent. saline are both grossly unphysiological solutions whose use is rarely justified.

(d) Vomiting. Gastric aspiration is essential in nearly all patients with acute tetraplegia, yet it has of ten been neglected in patients referred from other hospitals. Failure regularly to aspirate the stomach may result in acute gastric dilatation, lack of appreciation of the magnitude of the stress applied to the body's buffer systems and inhalation of vomitus. All of these difficulties may be obviated by routine gastric aspiration until intestinal function be sufficiently restored to absorb all gastrointestinal secretions and oral fluids administered at a rate of 25 to $50 \mathrm{ml}$. per hour.

(e) Inadequate Pulmonary Ventilation. All the metabolic disturbances following injury are associated with a reduction in the total concentration of the bicarbonate buffer components and a rise in hydrogen ion activity (Weisberg, 1962). Any associated hypoventilation will further stress the body's buffer systems and will result in a further fall in $\mathrm{pH}$.

(f) Inadequate Records. All patients on intravenous therapy require an accurate and dependable record of fluid intake and fluid losses, be they renal or extrarenal. Correction of body fluid and electrolyte disturbances and subsequent management of fluid, electrolyte and nutritional requirements cannot be achieved unless there can be reliance that orders will be meticulously followed and that records of intake and output will be accurately kept. It has been our experience that fluid balance records of patients referred from other hospitals have frequently been unreliable. Adequate records can only be achieved if all members of the nursing staff have repeatedly been informed of the purpose and value of the records.

\section{ASSESSMENT OF THE PATIENT}

On admission, as part of the general and special examination of the patient, it is essential to assess him with particular regard to fluid balance, nutritional state, and renal respiratory function prior to injury.

Fluid Balance. A patient admitted directly to a Spinal Unit and who was in good health before his injury may be assumed, if blood loss can be excluded, to be in normal fluid balance at the time of admission. Should he have been transferred from another hospital, however short his stay, particular attention must be paid to the volume, nature, and route of administration of any fluid which he may have received. This is necessary because there is always a tendency, in hospitals not regularly accepting cases of acute spinal injury, to confuse the hypotension of spinal shock with surgical shock and to overinfuse whole blood, plasma, plasma expanders, or 0.9 per cent. saline. It has been our experience that fluid overloading has of ten been of the order of five litres or more and that the fluid most commonly misused in this way has been 0.9 per cent. saline. The result of fluid overloading of this magnitude, depending on the patient's renal and cardiovascular reserve, has been considerable sodium overloading and acidosis and sometimes pulmonary oedema. 
Nutritional State. The basal metabolic requirement for a previously healthy patient is about $40 \mathrm{kcal}$. per sq. metre body surface per hour (Boothby, Berkson \& Dunn, I936) or, for the average adult, about I 500 to I $800 \mathrm{kcal}$. per day. Any caloric provision less than this must result in rapid depletion of glycogen stores and rapid mobilisation for energy needs of body fat and protein. Under these circumstances a negative nitrogen balance, apart from that consequent on muscle atrophy, is inevitable to meet the body's caloric needs. For as long as the caloric intake remains inadequate this degradation of body protein and fat will continue and the resulting starvation ketosis will impose an increasingly severe load on renal excretion of acidic and nitrogenous metabolic end-products. As renal function is commonly impaired, even though transiently, in spinal shock this may impose a severe load on the body's homeostatic mechanisms.

As patients with acute tetraplegia of ten have other injuries or infection their caloric requirement in the immediate post-injury phase is usually above the basal level.

Patients with associated disease at the time of injury may already be suffering from malnutrition and of particular significance in this respect are patients with associated gastro-intestinal or liver disease. The caloric needs of these patients may well exceed those of previously healthy persons.

Renal and Respiratory Function. It has already been indicated that acute spinal injury is always accompanied by significant and of ten considerable impairment of renal and respiratory function. These functions are of major importance in compensating for the metabolic consequences of injury. Pre-existing renal or respiratory disease such as chronic renal failure, chronic bronchitis, asthma or emphysema will seriously impair the body's compensatory mechanisms and will accentuate the adverse consequences of mismanagement of fluid and electrolyte therapy.

\section{PRINCIPLES OF METABOLIC MANAGEMENT}

There are certain principles of treatment which apply regardless of whether the patient was previously in good health and whether or not he has received excessive or inappropriate fluid therapy before being seen. These principles may briefly be stated:

(I) Blood loss must be rapidly corrected. It is of particular importance that the oxygen carrying capacity of the blood be restored and, depending on the circulatory state of the patient, packed or sedimented red cells may on occasions be more suitable than whole blood. Inf used saline is rapidly lost from the vascular compartment and does not constitute, even in emergencies, an adequate substitute for blood. Judicious use of peripheral vasoconstrictor drugs such as Aramine or nor-adrenaline may on occasions be warranted, but in most instances they are best avoided.

(2) Electrolyte concentrations must be kept, as far as possible, within normal limits. This should be achieved without undue stress on the volumes of the various body water compartments. The priority of correction of electrolyte disturbances is 
determined by their particular biological activity. Electrolytes in general do not exert an individual effect but the body responds rather to a pattern. Ions with the greatest specific biological activity, and which require earliest correction, are hydrogen and potassium. Calcium disturbances, because of the very large depot of calcium in bone, much of which is being mobilised due to inactivity, never need correction in cases of spinal injury by the addition of calcium. It is unlikely, also, that magnesium is required in adult patients, but the possibility of magnesium depletion in children should occasionally be considered. Wacker and Vallee (1958) have carefully reviewed magnesium metabolism and its disturbances in a number of clinical states. Our treatment includes the daily provision of $5 \mathrm{mEq}$. magnesium (Table III) but this is not believed to be of importance. All of the ions so far considered are present normally in low concentration in extracellular fluid and can exert no appreciable effect on osmolarity. Following correction of concentrations of ions with high specific biological activity it is necessary to correct any residual hypo-osmolarity (which is unlikely to be present unless there be significant loss of fluid from the gastro-intestinal tract) and acid-base imbalance. This involves the infusion of sodium together with chloride and a metabolisable anion such as lactate, acetate or bicarbonate. The ratio of anion is determined by the acid-base equilibrium, but chloride alone is almost always contraindicated, the only exception being when there is significant loss from the body of gastric juice.

(3) The body's continuing caloric requirements must be met. Calories are needed in order that essential catabolic processes may proceed with minimal degradation of body protein (Thoren, 1964). This involves, for an average adult, the provision of at least I 500 to I 800 kcals. per day, and it is probably better to try to achieve a daily caloric intake of 2000 or more kilocalories. Calories are also needed to provide the high-energy substrate for tissue repair and the eventual conversion of a negative to a positive nitrogen balance. A positive nitrogen balance, however, can never be achieved unless there be both an adequate non-nitrogen caloric intake to meet the body's catabolic energy requirements and an intake of amino nitrogen for incorporation into protein. The amino acids given must be carefully balanced and must be given concurrently with non-nitrogen calories to achieve their maximum utilisation in anabolic processes.

(4) It is essential that the various body fluid compartment volumes be kept as close as possible to normal. This may involve the correction of dehydration, the maintenance of an already normal fluid state, or the correction of overhydration. Because of the dangers of pulmonary oedema and circulatory overloading, and the possibility of increasing oedema of the cord at the site of injury, it is in general desirable to maintain the patient slightly underhydrated rather than overhydrated. This can only be assessed on clinical grounds. It is important to realise that insensible fluid loss in the tetraplegic patient is less than in the neurologically intact patient because of his inability to sweat below the level of lesion. For this reason, in an air-conditioned ward or in temperate climatic conditions, it is reasonable to assess insensible loss for the average tetraplegic adult at about $500 \mathrm{ml}$. per day.

(5) As a general principle it is always preferable to give fluid and nutrients by the oral route if possible. In the tetraplegic patient, however, the consequences of spinal shock are such that smooth muscle function almost invariably ceases for 
a variable period and oral feeding is impossible. The nearly complete cessation of gut function in spinal shock results in:

(i) accumulation of fluid in the stomach and small intestine. If the gastric fluid is not repeatedly withdrawn there may be vomiting with the associated danger of pulmonary aspiration of the vomitus;

(ii) dilatation of the hollow viscera of the abdomen. By pressure on the diaphragm this may constitute a further respiratory embarrassment;

(iii) failure of absorption from the small intestine. This means that oral feeding is impossible and that the fluid and electrolyte components of the intestinal secretions, while present in the gut, are functionally outside the body and their loss may impose a stress on fluid and electrolyte balances. Because of the failure of gut function all fluid and nutrients must be given intravenously and intravenous therapy must be maintained until there is unequivocal evidence of return of small intestinal function. Good bowel sounds should be present and the patient must demonstrate his ability to cope with small volumes of oral fluid bef ore the intravenous infusion is discontinued and the naso-gastric tube is removed.

\section{SCHEME OF TREATMENT}

While each patient must be individually assessed, a treatment schedule, based on the principles previously enumerated, has been developed. With minor variations in individual cases a previously fit adult tetraplegic admitted directly to the Spinal Unit is treated as follows:

(I) An indwelling Gibbon catheter is inserted into the bladder. Urine present in the bladder is disregarded for the purposes of fluid balance and all further urine is collected, measured and tested for albumin, blood, glucose and specific gravity. On occasions other tests, such as 24 -hour urea or total nitrogen excretion or urinary electrolytes, may be determined.

(2) A naso-gastric tube is passed and the stomach is thereafter aspirated hourly. The volumes of the aspirate are recorded and the aspirated material is not returned to the stomach. As required for balance purposes, electrolyte concentrations of the aspirated material are determined.

(3) Intravenous therapy is commenced through a $25-\mathrm{cm}$. polythene tube. This is maintained until the patient is able to tolerate oral fluids at the rate of about I00 $\mathrm{ml}$. per hour. The nature and rate of infusion of the intravenous fluids varies from day to day approximately as follows: For the first 24-hour period the patient receives $\mathrm{I} \frac{1}{2}$ litres Io per cent. fructose in a 4 to 6 per cent. $\mathrm{v} / \mathrm{v}$ ethyl alcohol solution, to which is added I6 U. regular insulin per litre and a multi-vitamin supplement. One or two grams of potassium chloride are inf used in the last eight hours of the first day. On the second day the patient receives $I \frac{1}{2}$ litres of Io per cent. fructose in a 4 to 6 per cent. $\mathrm{v} / \mathrm{v}$ alcohol solution with insulin and vitamins added as before. Depending on his urinary output $6 \mathrm{~g}$. potassium chloride are added to this solution. During the second day the patient also receives $\frac{1}{2}$ litre Hartmann's solution. On the third day the patient receives $\frac{1}{2}$ litre Hartmann's solution in four hours, and thereafter he receives approximately 3 litres per day by alternating 


\section{TABLE III}

The detailed Composition of the Infusion Solutions most commonly used in the Management of Acute Tetraplegia

\begin{tabular}{|c|c|c|c|c|c|c|c|c|c|c|}
\hline \multirow[b]{2}{*}{ Solution } & \multirow{2}{*}{$\begin{array}{c}\text { Total k cals } \\
\text { /litre } \\
\text { (approx) }\end{array}$} & \multirow{2}{*}{$\begin{array}{l}\text { Non nitrogen } \\
\text { k cals/litre } \\
\text { (approx) }\end{array}$} & \multirow{2}{*}{$\begin{array}{l}\text { Total amino } \\
\text { acids } \\
\text { g/litre }\end{array}$} & \multicolumn{7}{|c|}{ Electrolytes mEq/litre } \\
\hline & & & & $\mathrm{Na}^{+}$ & $\mathrm{K}^{+}$ & $\mathrm{Ca}^{++}$ & $\mathrm{Mg}^{++}$ & $\mathrm{Cl}^{-}$ & Acetate & Lactate \\
\hline $\begin{array}{l}10 \% \text { fructose } \\
\text { with } 4 \% \mathrm{v} / \mathrm{v} \text { alcohol } \\
\text { and potassium chloride }\end{array}$ & 625 & 625 & - & - & $\begin{array}{r}26 \\
52 \\
78 \\
104\end{array}$ & - & - & $\begin{array}{r}26 \\
52 \\
78 \\
104\end{array}$ & - & - \\
\hline $\begin{array}{l}10 \% \text { fructose } \\
\text { with } 6 \% \mathrm{v} / \mathrm{v} \text { alcohol } \\
\text { and potassium chloride }\end{array}$ & 740 & 740 & - & - & $\begin{array}{r}26 \\
52 \\
78 \\
104\end{array}$ & - & - & $\begin{array}{r}26 \\
52 \\
78 \\
104\end{array}$ & - & - \\
\hline $\begin{array}{l}20 \% \text { fructose } \\
\text { with } 6 \% \mathrm{v} / \mathrm{v} \text { alcohol } \\
\text { and potassium chloride }\end{array}$ & 1150 & 1150 & - & - & $\begin{array}{r}52 \\
78 \\
104\end{array}$ & - & - & $\begin{array}{r}52 \\
78 \\
104\end{array}$ & - & - \\
\hline Aminofusin 850 & 850 & 650 & 50 & 35 & 25 & - & 5 & 55 & 35 & - \\
\hline Aminofusin forte & 800 & 400 & 100 & 35 & 25 & - & 5 & 55 & 35 & - \\
\hline Hartmann's solution & - & - & - & 131 & 6 & 4 & - & 112 & - & 29 \\
\hline
\end{tabular}

The varying potassium and chloride concentrations in the fructose 
8-hourly litres of a Io per cent. fructose solution with added alcohol, insulin, potassium chloride and vitamins, and 4-hourly $\frac{1}{2}$ litres of Aminofusin (Pfrmmer), a solution of synthetic crystalline amino acids. The detailed compositions and caloric values of these solutions are given in Tables III and IV.

\section{TABLE IV}

The Synthetic Amino-acid Composition of the two Aminofusin Solutions commonly used

(Note: Arginine, Isoleucine, Leucine, Lysine, Threonine and Histidine are present only in the naturally occurring and readily useable laevorotatory isomeric form.)

Aminofusin 850

\begin{tabular}{|l|c|c|}
\hline 1 -Arginine HCl & 3.99 & 7.97 \\
\hline Glycine & 24.00 & 48.00 \\
\hline 1 -Isoleucine & 4.40 & 8.80 \\
\hline 1 -Leucine & 2.30 & 4.60 \\
\hline 1 -Lysine HCl & 2.50 & 5.00 \\
\hline dl-Methionine & 2.40 & 4.80 \\
\hline dl-Phenylalanine & 3.60 & 7.20 \\
\hline 1 -Threonine & 2.40 & 4.80 \\
\hline dl-Tryptophane & 1.00 & 2.00 \\
\hline dl-Valine & 3.20 & 6.40 \\
\hline 1 -Histidine HCl & 1.23 & 2.47 \\
\hline
\end{tabular}

Each solution contains sorbitol $10 \%$ and Aminofusin 850

This regime after the second day provides approximately $2100 \mathrm{kcals}$. $/ \mathrm{day}$. If for any reason it is considered desirable further to increase the patient's caloric intake 20 per cent. fructose may be substituted for Io per cent. in which case the daily caloric intake is $2900 \mathrm{kcal}$. The amino-acid intake on this regime is either $50 \mathrm{~g}$. or $100 \mathrm{~g}$. per day. The potassium intake is 77 to $233 \mathrm{mEq}$. per day-it may still further be increased if necessary.

\section{RATIONALE OF INTRAVENOUS THERAPY}

Fluid Volumes. These have been designed to keep the patient in fluid balance with a urinary output of two to three litres per day. If for any reason the urinary volumes are significantly more or less than this, the volume of intravenous fluid is adjusted accordingly.

Electrolytes. The electrolyte composition of this regime has been designed to cover the continuing gastro-intestinal losses, to impose a minimal electrolyte 
load on the kidney and to achieve and maintain normal extracellular and intracellular patterns and normal buffer concentrations. We would draw attention to the relatively high potassium requirements and to the fact that recovery of smooth muscle function will be delayed unless these requirements be met. In many patients extra bicarbonate ion is required to correct the buffer systems and it is our practice to meet these requirements by adding 20 or $40 \mathrm{ml} .8 .7$ per cent. (saturated) sodium bicarbonate to a litre of intravenous fluid as required. This concentrated sodium bicarbonate solution contains I mEq. per $\mathrm{ml}$.

Calories. Calories are provided in this regime in four forms, fructose, alcohol, sorbitol and synthetic amino acids. Fructose is preferred to glucose because it is much less likely, in solutions more concentrated than 5 per cent. to cause thrombophlebitis. It has the further advantage of entering the Embden-Meyerhof glycolytic pathway more readily than glucose and of having a metabolism at least partly independent of insulin (Leuthardt \& Wolf, I963).

Alcohol is used as a further caloric source $(5.6 \mathrm{kcal}$. per ml.), because it acts as a very mild sedative and also because it has a peripheral local venodilator effect, thereby further minimising any tendency to thrombophlebitis with concentrated hexose solutions.

Sorbitol is used in the synthetic amino-acid solutions because it is relatively non-reactive in vitro and therefore does not react with the amino acids in solution as would occur with a more reactive sugar such as glucose or fructose. Like the other sugars it has a calorific value of approximately $4 \mathrm{kcal}$. per gram.

The above three substances are all employed to meet the body's energy requirements and to spare body protein. Only when that has been achieved can amino acids usefully be employed to enter into anabolic processes leading to protein synthesis. In the presence of a high non-nitrogen caloric intake crystalline synthetic amino acids of 50 or $100 \mathrm{~g}$. per day are administered to allow repair of body protein. Stohl and Blackfan (I940), who used intravenous synthetic amino acids in infants, were probably the first workers to show that a positive nitrogen balance could be achieved in this way in humans. With a high non-nitrogen caloric intake intravenous synthetic amino acids can readily be incorporated into body protein and utilisation exceeding 90 per cent. has been shown in rabbits by Griem and Lang (I960) and in man by Muller, et al. (I962).

Insulin. Insulin is used to facilitate carbohydrate metabolism but more importantly to promote potassium and amino-acid uptake by cells. It is quite probable that in many cases endogenous insulin would be adequate to facilitate potassium and amino-acid uptake. Munro, Black and Thomson (1959) have shown that infused glucose, presumably by stimulating insulin release from islet cells, enhances the deposition of amino acids as protein in rat muscle and Munro (1963) has recently reviewed the interaction of carbohydrate, amino acids and insulin in facilitating protein synthesis. It should be remembered, however, that where fructose and sorbitol are inf used instead of glucose there is not the same stimulation of endogenous insulin production, and for that reason it is our policy to add I6 units of insulin to each litre of ro per cent. fructose and 24 units of insulin to each litre of 20 per cent. fructose. This is done so that relative insulin deficiency is avoided as a rate limiting factor in cellular uptake of potassium and amino acids. 


\section{MANAGEMENT OF PATIENTS WITH PRE-EXISTING DISEASE}

The metabolic management of tetraplegic patients with pre-existing disease depends entirely on its nature and severity. In general, the associated conditions most likely to be encountered are renal disease, cardiac failure, hepatic disease and respiratory disease. The principles of treatment remain the same, but special care may have to be exercised to avoid an excessive renal solute load or circulatory overloading with peripheral and pulmonary oedema. In the case of hepatic disease it is essential to provide adequate calories and also adequate amino acids, particularly methionine and arginine.

\section{MANAGEMENT OF PATIENTS WITH FLUID OVERLOADING}

In our experience overhydrated patients have usually received in another Centre a rapid infusion of 0.9 per cent. sodium chloride or 4 per cent. dextrose in 0.18 per cent. sodium chloride. It is essential in these cases to promote a diuresis as rapidly as possible before instituting other treatment. This diuresis can most readily be achieved by the rapid infusion (in about 20 minutes) of $\frac{1}{2}$ litre 20 per cent. mannitol solution and this treatment may be repeated after a few hours if necessary. Intravenous urea may likewise be used as an osmotic diuretic but mannitol would seem to be preferable in most cases. Fluid overloading, however, represents a grave hazard in the management of tetraplegic patients and it is probable that more deaths occur directly or indirectly from this cause than from any other. The reasons for this are intimately associated with the principles of treatment previously discussed. It has been shown that adequate metabolic management requires the daily provision of some 2000 to 3000 calories, 50 to I00 grams of amino acids, up to $300 \mathrm{mEq}$. per day potassium and sufficient bicarbonate or bicarbonate precursor to correct buffer systems. Blood may also be required. There is an irreducible minimum fluid volume which is required, even utilising the most concentrated solutions possible, in order that these criteria of treatment may be fulfilled. If the tetraplegic patient has the added need of a negative fluid balance to correct an overloaded circulation and pulmonary oedema, then it is obvious that his other requirements cannot be met, or that even in partially meeting them his fluid status will be further disturbed. With this combination of fluid overloading and inadequate metabolic treatment there must be inevitably a high mortality.

\section{RESULTS}

This paper is based on a consecutive series of 129 patients with acute cervical injuries admitted to the Spinal Injuries Centre for Victoria during the five years from July I959 to June I964. These patients have been classified in the manner proposed by Tribe (1963) and the term 'acute death' implies that death took place within two months of the injury. In addition, complete lesions of the cervical spinal cord have been separated from incomplete lesions and respiratory deaths 
TABLE V

Analysis of the Results achieved in a Consecutive Series of 237 Acute Spinal Cord Injuries with special reference to Acute Respiratory Deaths

\begin{tabular}{|c|c|c|c|c|c|c|c|c|c|}
\hline & \multicolumn{2}{|c|}{$\begin{array}{l}\text { ALL ACUTE } \\
\text { SPINAL CORD } \\
\text { INJURIES }\end{array}$} & \multicolumn{2}{|c|}{$\begin{array}{l}\text { DORSAL AND } \\
\text { LUMBAR LESIONS }\end{array}$} & \multicolumn{2}{|c|}{$\begin{array}{l}\text { ALL CERVICAL } \\
\text { LESIONS }\end{array}$} & \multicolumn{3}{|c|}{$\begin{array}{l}\text { COMPLETE CERVICAL } \\
\text { LESIONS }\end{array}$} \\
\hline Year & Admissions & $\begin{array}{l}\text { Acute } \\
\text { Deaths }\end{array}$ & Admissions & $\begin{array}{l}\text { Acute } \\
\text { Deaths }\end{array}$ & Admissions & $\begin{array}{l}\text { Acute } \\
\text { Deaths }\end{array}$ & Admissions & $\begin{array}{l}\text { Acute } \\
\text { Deaths }\end{array}$ & $\begin{array}{c}\text { Acute } \\
\text { Respiratory } \\
\text { Deaths }\end{array}$ \\
\hline $1959-60$ & 56 & 6 & 31 & 1 & 25 & 5 & 10 & 5 & 5 \\
\hline $1960-61$ & 45 & 5 & 21 & 2 & 24 & 3 & 10 & 2 & 2 \\
\hline $1961-62$ & 47 & 3 & 20 & 1 & 27 & 2 & 13 & 1 & 0 \\
\hline $1962-63$ & 42 & 0 & 18 & 0 & 24 & 0 & 6 & 0 & 0 \\
\hline $1963-64$ & 47 & 4 & 18 & 1 & 29 & 3 & 8 & 2 & 1 \\
\hline TOTALS & 237 & 18 & 108 & 5 & 129 & 13 & 47 & 10 & 8 \\
\hline
\end{tabular}


TABLE VI

Details of the Eight Cases of Acute Respiratory Death in 129 Consecutive Complete Cervical Spinal Cord Lesions

\begin{tabular}{|c|c|c|c|c|c|c|c|c|c|c|}
\hline No. & Sex & Age & $\begin{array}{c}\text { Time } \\
\text { Before } \\
\text { Admission }\end{array}$ & Lesion & $\begin{array}{l}\text { Excess } \\
\text { Fluid }\end{array}$ & $\begin{array}{l}\text { Inadequate } \\
\text { Respiratory } \\
\text { Management }\end{array}$ & $\begin{array}{l}\text { Patients } \\
\text { Turned } \\
\text { Too Soon }\end{array}$ & Associated Conditions & $\begin{array}{l}\text { Day } \\
\text { of } \\
\text { Death }\end{array}$ & $\begin{array}{l}\text { Death } \\
\text { Considered } \\
\text { Avoidable }\end{array}$ \\
\hline $1 / 1959$ & M & 45 & $3 \mathrm{hrs}$ & C4 & Yes & Yes & Yes & None & 3 & Yes \\
\hline $2 / 1959$ & M & 67 & 3 days & C5 & Yes & Yes & No & $\begin{array}{l}\text { Admitted } 3 \text { days after } \\
\text { accident with bilateral } \\
\text { bronchopneumonia and } \\
\text { urinary tract infection }\end{array}$ & 9 & No \\
\hline $3 / 1959$ & $\dot{\mathbf{F}}$ & 29 & $4 \mathrm{hrs}$ & C6 & Yes & Yes & Yes & $\begin{array}{l}\text { Fluid overloading ( } 2.3 \\
\text { litres in } 4 \text { hours) be- } \\
\text { fore admission }\end{array}$ & 10 & Yes \\
\hline $4 / 1960$ & M & 74 & $8 \mathrm{hrs}$ & C5 & No & Yes & No & None & 7 & Yes \\
\hline $5 / 1960$ & M & 20 & $8 \mathrm{hrs}$ & C5 & Yes & Yes & No & None & 7 & Yes \\
\hline $6 / 1960$ & $\mathbf{M}$ & 33 & $12 \mathrm{hrs}$ & C4 & No & Yes & No & None & 10 & Yes \\
\hline $7 / 1960$ & $\mathbf{M}$ & 20 & $\frac{1}{2} \mathrm{hr}$ & C4 & No & No & No & $\begin{array}{l}\text { Aspiration of river water } \\
\text { into lungs: pre-existing } \\
\text { acute bronchitis: en- } \\
\text { vironmental hyperthermia }\end{array}$ & 6 & No \\
\hline $8 / 1964$ & $\mathbf{M}$ & 23 & $10 \mathrm{hrs}$ & $\begin{array}{l}\text { Spino- } \\
\text { medullary } \\
\text { Transection }\end{array}$ & No & No & No & $\begin{array}{l}\text { Complete spino-medullary } \\
\text { transection due to at- } \\
\text { lanto-axial dislocation }\end{array}$ & 17 & No \\
\hline
\end{tabular}


from other causes of death. The separation is made because it is felt that the number of acute respiratory deaths which occurs in complete cervical cord lesions provides the only valid criterion for the judgment of the results of the proposed regime of treatment (Cheshire, I964). It will be seen (Table V) that there have been eight respiratory deaths in forty-seven complete lesions of the cervical cord. These eight cases have been considered in more detail in Table VI, with particular reference, in the light of subsequent experience, to adequacy of respiratory management, the possibility of fluid overloading, and premature turning of the patient. It is considered that in three of the cases associated disease or the nature of the injury were the direct and inevitable cause of death. In the other five cases (all occurring in the first year of this series) it is believed that, with better management of the patients, a fatal outcome could have been avoided.

For completeness, all acute spinal cord injuries have been classified, and there have been a total of 18 acute deaths in a series of 237 admissions. Of the Io deaths which occurred in patients other than the complete cervical cord series, only one was an acute respiratory death. The other nine deaths were due to head injuries (2), cerebral abscess, congestive cardiac failure, myocardial infarction, pulmonary embolus (2), hepatic failure and aortic thrombosis.

\section{SUMMARY}

The management of the respiratory problems of acute traumatic tetraplegia has been discussed in previous papers. This paper presents a modification and extension of the same subject and, in addition, attempts to correlate the respiratory and metabolic facets of management into a pattern of treatment which will maintain adequate alveolar ventilation and nutrition and a normal fluid and electrolyte balance.

The maintenance of adequate alveolar ventilation may be threatened by:

(I) increasing paralysis of the muscles of respiration;

(2) the supervention of either pulmonary consolidation or collapse. These complications are related to the aspiration of vomitus, the inability to deliver sputum to the mouth, and the inspissation of sputum;

(3) pulmonary oedema, due to over-hydration of the patient.

Arising from a knowledge of these potential complications, a respiratory regime is presented, which includes the timely use of tracheostomy and intermittent positive pressure respiration. In the management of a patient with a tracheostomy, the importance of the humidification of the inspired air, and frequent and adequate bronchial suction is stressed.

The effect of body temperature or the oxygen requirements of the tetraplegic patient is also discussed, and the suggestion is made that there may be advantages in nursing such a patient at 34 to $35^{\circ} \mathrm{C}$.

The patient with acute traumatic tetraplegia may show one or more of a number of disturbances of function, each of which may stress homeostatic mechanisms for fluid and electrolyte. In particular, shock, paralytic ileus, vomiting and acute renal failure are common and gastric aspiration and intravenous infusion are 
almost always required. Among the more common disturbances of fluid, electrolyte and acid-base balance which must be prevented are:

(I) Respiratory acidosis.

(2) Alkalosis associated with loss of gastric hydrochloric acid.

(3) Acidosis associated with loss of small intestinal secretions. This loss may be external or into dilated gut.

(4) Acidosis associated with starvation-this may be made worse by coexisting hypoventilation or acute renal failure.

(5) Hypokalaemia.

The final pattern which may require correction by intravenous therapy could be the resultant of any combination or all of these disturbances. The principles of intravenous therapy are discussed.

\section{RÉSUMÉ}

Le traitement des problèmes respiratoires au décours de la période aigue de la tétraplégie traumatique a été discuté dans les articles précédents. Notre communication présente une modification, en même temps qu'une extension, sur le même sujet, er de plus, essaie de correler les aspects métaboliques et respiratoires dans un système de traitement destiné à maintenir une ventilation alvéolaire correcte, ainsi qu'un bon équilibre électrolytique, nutritionnel et humoral.

La ventilation alvéolaire peut être menacée par:

(I) l'aggravation de la paralysie des muscles respiratoires;

(2) l'apparition d'une consolidation, ou collapsus pulmonaire:

- par l'aspiration de vomissement,

- l'incapacité d'expectoration,

-la rétention des sécrétions bronchiques;

(3) l'oedème pulmonaire dû à l'hyper-hydration du malade.

En vue de ces complications possibles, un schéma de traitement respiratoire est présenté comprenant l'indication, à temps, de la trachéotomie et de la respiration intermittente par pression positive.

Chez un trachéotomisé, l'importance de l'humidification de l'air, ainsi que des aspirations bronchiques fréquentes, est présentée, Les effets de la température du corps sur les besoins en oxygène du tétraplégique sont discutés. Il est suggéré qu'il y aurait avantage à soigner de tels malades à une température corporelle de $34-35^{\circ}$.

Ces malades peuvent présenter plusieurs complications nécessitant un contrôle humoral. En particulier, le choc, l'iléus paralytique, les vomissements et l'insuffisance rénale aiguë nécessitant presque toujours aspirations et perfusions.

Parmi les déséquilibres humoraux, électrolytiques, et acidobasiques qui sont à éviter:

(I) l'acidose respiratoire;

(2) l'alcalose par perte de l'acide chlorydrique gastrique;

(3) l'acidose, par perte de sécrétions au niveau de l'intestin grêle;

(4) l'acidose, par dénutrition, aggravée par l'hypo-ventilation ou l'insuffisance rénale aigue;

(5) l'hypo-kaliémie.

La correction de ces troubles par perf usion intra-veineuse tient compte de l'association de plusieurs, ou de tous ces troubles. Ses principes sont discutés. 


\section{ZUSAMMENFASSUNG}

In einer früheren Veröffentlichung wurde über die Behandlung respiratorischer Probleme berichtet. Die jetzige Publikation beschäftigt sich mit der Modifizierung und Erweiterung dieses Problems. Ausserdem wurde versucht eine Korrelation der respiratorischen und metabolischen Gesichtspunkte für einen gemeinsamen Arbeitsplan zu finden, der die Aufrechterhaltung einer ausreichenden Ventilation und Ernährung sowie ein normales Flüssigkeits- und Elektrolytengleichgewicht gewährleistet.

Die Aufrechterhaltung adequater alveolarer Ventilation kann bedroht werden:

(I) durch zunehmende Lähmung der Atmungsmuskeln;

(2) durch die Addition von pulmonaler Konsolidierung oder Kollaps;

(3) Lungenoedem durch Überwässerung.

Diese Komplikationen entstehen durch Aspiration von Vomitus, Unfähigkeit Sputum zum Mund zu bringen und die Eindickung von Sputum. Aus der Erkenntnis dieser potentionellen Komplikationen wurde ein respiratorisches Behandlungsschema entwickelt, das die zeitgemässe Anwendung der Tracheotomie und intermittierende positive Druckatmung einschliesst.

Der Einfluss von Körpertemperatur auf den Sauerstoff-bedarf bei Tetraplegikern wird ebenfalls diskutiert und die Vorteile, solche Patienten unter einer Temperatur von 34$35^{\circ} \mathrm{C}$. zu halten, betont.

Die verschiedenen Funktionsstörungen im akuten Stadium der Tetraplegie können zu Schwierigkeiten in der Flüssigkeits und Elektrolytenhomeostatik führen. Inbesondere sind Schock, paralytischer Ileus, Erbrechen und akute Niereninsuffizienz häufig, und Magenaspiration und intravenöse Inf usion sind fast immer notwendig. Unter den gewöhnlichen Störungen des Flüssigkeits-, Elektrolyten und Säure-Basengleichgewichts, die zu vermeiden sind, sind folgende zu nennen:

(I) Respiratorische Acidosis;

(2) Alkalose verbunden mit Verlust von Magensäure;

(3) Acidosis verbunden mit Verlust der Dünndarmsekretion;

(4) Acidosis assoziiert mit Hunger, die durch bestehende Hypoventilation und akute Niereninsuffizienz verschlimmert werden kann;

(5) Hypokalämie.

Aus der Kombination von einigen oder allen diesen Störungen ergibt sich schliesslich die Situation, welche intravenöse Therapie erfordert, deren Prinzipien diskutiert werden.

\section{ACKNOWLEDGEMENTS}

We wish to thank Dr. G. C. Price for assistance with the respiratory management of these patients, and for the bronchoscopies performed. Our thanks are also due to Dr. Grant Pattison for assistance with the biochemical investigations.

The authors would like to express their gratitude to J. Pf rimmer \& Co. of Erlangen, Western Germany, for the supplies of Aminof usin used in this study for clinical evaluation.

\section{REFERENCES}

Begelow, W. G., Lindsay, W. K., Harrison, R. C., Gordon, R. A. \& Greenwood, W. F. (1950). Amer. F. Physiol., 160, I25.

Benedict, F. G. \& LeE, R. C. (I938). Carnegie Institute Publ. No. 497. Washington.

Bergofsky, E. H. (1964). Arch. phys. Med., 45, 575.

Boothby, W. M., Berkson, J. \& Dunn, H. L. (1936). Amer. F. Physiol., II6, 468.

BREMNER, C. G. (I962). Brit. F. Dis. Chest, 56, 39.

Cameron, G. S., Scott, J. W., Jousse, A. T. \& Botterell, E. H. (1955). Ann. Surg., I4I, $45 \mathrm{I}$. 
Cheshire, D. J. E. (1964). Int. F. Paraplegia, I,, 252.

Cheshire, D. J. E. \& Foster, K. M. (1964). Int. f. Paraplegia, 2, I4I.

Coller, F. A. \& MADDOCK, W. G. (I940). Surg. Gynec. Obstet. 70, 340.

Elkington, J. R. \& Tarail, R. (I950). Amer. F. Med. 9, 200.

Geyer, R. P. (I960). Physiol. Rev. 40, I5O.

Grant, A. F., Wright, J. S. \& Clifton, B. S. (I962). Med. F. Aust. I, 349.

GrIEM, W. \& LANG, K. (1960). Klin. Wschr. 38, 336.

Hemingway, A., Bors, E. \& Hobby, R. P. (I958). F. clin. Invest. 37, 773.

Horvath, S. M., Hull, B. K., SpurR, G. B. \& Stevens, G. E. (I953). Science, II8, IOO.

Leuthard, F. \& Wolf, H. P. (1963). Proceedings of an International Symposium on the

Clinical and Metabolic Aspects of Laevulose, Royal Society of Medicine, pp. 4-I8.

Levine, R. (1959). Carbohydrate Metabolism. In Diseases of Metabolism, edited by S. G.

Duncan, 4th ed. p. 66. Philadelphia \& London: W. B. Saunders Co.

Marks, L. J. (1950). Ann. Surg. 132, 20.

Meade, J. W. (I961). New Engl. F. Med. 265, 519.

Muller, G., Trapp, P., BANSI, H. W. \& Rostin, M. (1962). Klin. Wschr. 40, 436.

Munro, H. N., Black, J. G. \& Thomson, W. S. R. (1959). Brit. F. Nutr. 13, 475.

NeGUS, V. E. (I949). Thorax, 4, 57.

SARA, C. (1965). Med. F. Aust. I, 99.

Sara, C. \& Currie, T. (1965). Med. F. Aust. I, I74.

SiggaARD ANDERSEN, D., ENGEl, K., Jørgensen, K. \& Astrup, P. (I960). Scand. F. clin. Lab. Invest. 12, 172.

SiggaARD ANDERSEN, O. (I96I). Scand. F. clin. Lab. Invest. 14, 6.

SMITh, L. W. \& Fay, T. (I940). Amer. F. Clin. Path. Io, I.

Stohl, A. T. \& BlaCkFAN, K. D. (1940). F. Nutr. 20, 305.

TARAIL R. \& Elkington, J. R. (I949). F. clin. Invest. 28, 99.

TAYLOR, A. B. (1960). Brit. F. Dis. Chest. 54, I57.

THOREN, L. (1964). Acta chir. scand. Supp. 325, 75.

TRIBE, C. R. (1963). Int. F. Paraplegia, I, I9.

WaCker, W. E. C. \& ValleE, B. L. (I958). New Engl. F. Med. 259, 43I, 475.

WatTs, J. McK. (1963). Brit. F. Surg. 50, 954.

WeISBERG, H. F. (I962). In Water Electrolyte and Acid-Base Balance, and ed. pp. 222-224. Baltimore, Md.: Williams \& Wilkins. 